\title{
Pemetaan Kebisingan Menggunakan Software Golden Surfer 11 di Kawasan Universitas PGRI Palembang
}

\author{
Apriadi Ramadoni ${ }^{1}$, Jumingin ${ }^{2 *}$, Sagita Charolina Sihombing ${ }^{3}$ \\ *e-mail: jumingin@univpgri-palembang.ac.id \\ 1,2,3 Program Studi Fisika, Fakultas Sains dan Teknologi Universitas PGRI Palembang \\ 30251, Indonesia
}

\begin{abstract}
Noise mapping in the Palembang PGRI University area using the Golden Surfer 11 Software was carried out in March 2021. This study aims to determine the noise level and mapping noise level using software golden surfer 11. The method used is the purposive sampling method and the frequency distribution in order to obtain Leq noise level data. Data processing uses the frequency distribution method to find out how big the overall average noise level is. The average value of the noise level is collected and a noise contour map is made to find where the noise distribution is greatest. The results obtained indicate that at each measurement point the noise level has passed the quality standard limit except when the measurement is carried out in the morning, the noise level that exceeds the limit in the vehicle parking area and the main entrance of the campus is indicated by a noise contour maps.
\end{abstract}

Keywords: PGRI Palembang University, noise, mapping, Surfer 11.

\begin{abstract}
ABSTRAK
Pemetaan kebisingan di kawasan Universitas PGRI Palembang menggunakan Software Golden Surfer 11 telah dilakukan pada bulan Maret 2021. Penelitian ini bertujuan untuk mengetahui tingkat kebisingan suara dan memetakan tingkat kebisingan suara menggunakan Software Golden Surfer 11. Metode yang digunakan adalah metode purpossive sampling dan distribusi frekuensi sehingga didapat datadata tingkat kebisingan suara $\mathrm{L}_{\mathrm{eq}}$. Pengolahan data menggunakan metode distribusi frekuensi untuk dicari seberapa besar tingkat kebisingan suara rata-rata secara keseluruhan. Nilai rata-rata tingkat kebisingan dikumpulkan dan dibuat peta kontur kebisingan suara untuk dicari dimana persebaran kebisingan yang paling besar. Hasil yang diperoleh menunjukkan bahwa di setiap titik pengukuran tingkat kebisingannya telah melewati batas baku mutu kecuali pada saat pengukuran dilakukan pagi hari, tingkat kebisingan yang melebihi batas pada area parkir kendaraan dan pintu masuk utama kampus ditunjukkan oleh peta kontur kebisingan.
\end{abstract}

Kata Kunci: Universitas PGRI Palembang, kebisingan, pemetaan, Surfer 11.

\section{PENDAHULUAN}

\begin{abstract}
Perguruan tinggi merupakan tempat diselenggarakannya pendidikan tinggi untuk menjadi anggota masyarakat yang memiliki akademis, professional dan menciptakan ilmu pengetahuan. Saputra dkk (2016) mengemukan
\end{abstract}

kawasan kampus memerlukan lingkungan yang tenang dan jauh dari kebisingan, perkotaan yang identik dengan kepadatan lalu lintas dapat menjadi kendala yang mempengaruhi kenyamanan dalam proses belajar mengajar. 
Penelitian ini berdasarkan Surat Keputusan Menteri Lingkungan Hidup No. 48/MENLH/11/1996, menyatakan tingkat kebisingan di lingkungan kampus yang diperbolehkan adalah $55 \mathrm{~dB}$. Tujuan dari penelitian ini adalah untuk mengetahui tingkat kebisingan suara dan memetakan persebaran kebisingan di kawasan kampus A Universitas PGRI Palembang. Penelitian terdahulu oleh Atina dkk (2020) menyatakan bahwa tingkat kebisingan yang terukur di lingkungan kampus A Universitas PGRI Palembang belum memenuhi standar baku mutu pemerintah untuk lembaga pendidikan yaitu $55 \mathrm{~dB}$. Berdasarkan dari penelitian tersebut timbul keinginan untuk mengetahui bagaimana persebaran kebisingannya apabila dibuat dalam bentuk peta kontur.

Pembuatan peta kontur yang menggambarkan tingkat kebisingan kampus A Universitas PGRI Palembang akan menggunakan program Golden Surfer 11. Surfer adalah salah satu perangkat lunak yang digunakan untuk pembuatan peta kontur dan pemodelan tiga dimensi yang berdasarkan pada grid (Ahmad dkk, 2018).

Berdasarkan penjelasan diatas maka batasan masalahnya adalah bagaimana hasil peta kontur tingkat kebisingan yang terjadi dengan parameter berupa tingkat kebisingan yang tersebar di berbagai titik pengukuran. Harapan dari penelitian ini dapat memberikan gambaran peta persebaran tingkat kebisingan yang terjadi di lingkungan kampus A Universitas PGRI Palembang sehingga dapat menjadi informasi bagi kemajuan dunia pendidikan khususnya Universitas PGRI Palembang.

\section{BAHAN DAN METODE}

Penelitian ini menggunakan metode pengambilan data secara purposive sampling berdasarkan kriteria tertentu dimana data primer yang diambil berupa tingkat kebisingan yang terukur yang tersebar di berbagai titik pengukuran (Jumingin dan Atina, 2019). Data tingkat kebisingan yang diambil berada di lantai 3 pada masing-masing gedung yang ada di dalam kawasan kampus A Universitas PGRI Palembang. Hal ini untuk menghindari noise yang muncul akibat dari aktivitas pembelajaran. Waktu pengukuran berdasarkan Kepmen LH No. 48 (1996) tentang baku tingkat kebisingan dimana pembagian waktu akan dimulai dari pengukuran pagi mewakili $\mathrm{L}_{1}(06.00-$ 09.00) dengan waktu pengambilan data kebisingan diambil pada Jam 07.00, pengukuran siang mewakili $\mathrm{L}_{2}(09.00-$ 14.00) dengan waktu pengambilan data kebisingan diambil pada Jam 10.00 dan pengukuran sore mewakili $\mathrm{L}_{3}$ (14.00 17.00) dengan waktu pengambilan data kebisingan diambil pada Jam 15.00.

Penelitian dilakukan pada Maret 2021 dengan lokasi titik pengukuran berjumlah 8 titik yang tersebar dari gedung A sampai dengan gedung $\mathrm{H}$ kampus. Penelitian dilakukan secara kuantitatif dengan melihat data tingkat kebisingan yang tertera langsung dari alat selama 10 menit di setiap titik secara bersamaan dan kemudian dicatat kedalam tabel pengamatan selama 6 hari waktu perkuliahan.

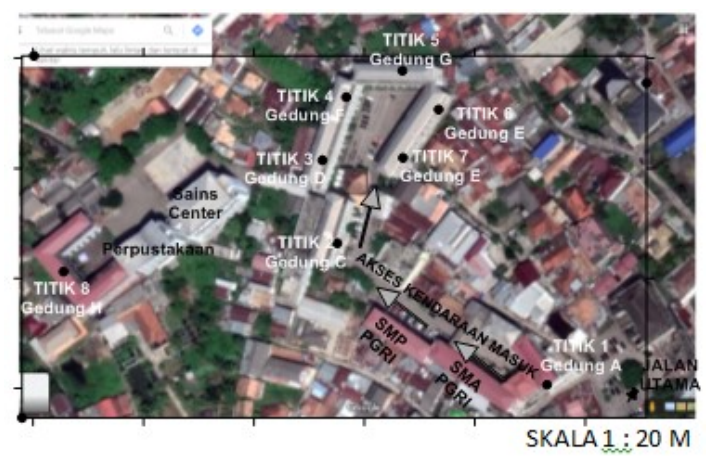

Gambar 1. Lokasi Pengukuran

Alat dan bahan yang digunakan pada penelitian ini diantaranya:

1. Sound Level Meter Lutron Sl-4011

2. Stopwatch 


\section{GPS Garmin Map 60 CS \\ 4. Software Golden Surfer 11}

Prosedur kerja menggunakan alat instrumen Sound Level Meter Lutron Sl4011 memakai petunjuk dari SNI 7231. 2009 tentang Metode Pengukuran Intensitas Kebisingan di Tempat Kerja.

Diagram alir penelitian secara garis besar ditunjukan oleh Gambar 2 berikut:

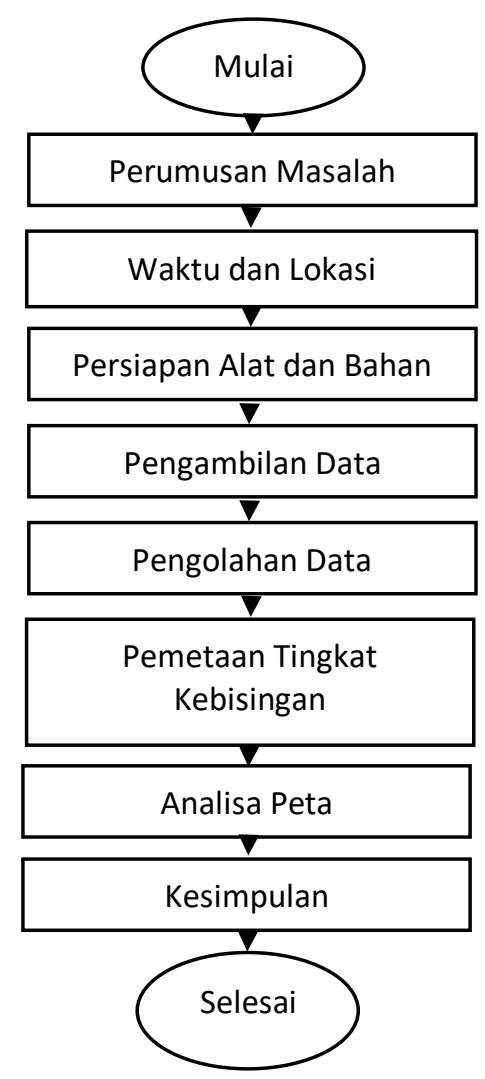

Gambar 2. Diagram Alir Penelitian

\footnotetext{
Pengolahan data tingkat kebisingan menggunakan bantuan program Microsoft Excel 2010 untuk mencari nilai rata -rata kebisingan di setiap titik selama 6 hari perkuliahan. Sumiyati dan Suboyo (2008) menyatakan kebisingan $\mathrm{L}_{50}, \mathrm{~L}_{1}$ dan $\mathrm{L}_{\mathrm{eq}}$ dapat dicari menggunakan metode distribusi frekuensi $\mathrm{L}_{50}$. $\mathrm{L}_{50}$ adalah persentase tengah $50 \%$ dari data pengukuran yang umumnya identik dengan nilai kebisingan rata-rata, sedangkan $L_{1}$ adalah persentase $1 \%$ dari
}

99\% data pengukuran yang umumnya adalah nilai kebisingan maksimum atau nilai kebisingan yang menyebabkan gangguan. Kedua nilai tersebut menjadi dasar dalam pencarian nilai kebisingan equivalent angka penunjuk $\left(\mathrm{L}_{\mathrm{eq}}\right)$ yang nilainya setara dengan nilai kebisingan tetap selama waktu pengukuran (Aulia, 2018). Berdasarkan penjelasan di atas maka perhitungan nilai kebisingan Leq dapat dicari menggunakan rumus:

$L_{e q}=L_{50}+0.43 \cdot\left(L_{1}-L_{50}\right)$

Ketiga variabel nilai kebisingan tersebut akan dibandingkan dengan nilai ambang batas yang ditetapkan oleh peraturan pemerintah sebesar $55 \mathrm{~dB}$ sesuai dengan periode waktu pengukuran nya.

Pemetaan tingkat kebisingan berdasarkan nilai kebisingan Leq sebagai target yang dituju dengan bantuan titik koordinat $\mathrm{x}$ dan $\mathrm{y}$ yang didapat menggunakan alat bantu GPS di setiap titik pengukuran. Nilai kebisingan $\mathrm{L}_{\mathrm{eq}}$ di setiap titik masuk ke dalam spreadsheet program Surfer 11 dan selanjutnya dilakukan proses Grid - Plot sehingga menghasilkan suatu peta kontur yang berjumlah 3 mewakili setiap periode pada saat pengukuran.

Peta kontur tingkat kebisingan mempunyai kategori beberapa warna yang mewakili seberapa besar tingkat kebisingan yang berada di titik terrsebut. Berikut ini merupakan zona warna yang akan digunakan pada penelitian ini:

$:<50 \mathrm{~dB} \quad$ (Biru)
$: 50 \mathrm{~dB}-55 \mathrm{~dB}$ (Biru - Hijau)
$: 55 \mathrm{~dB}-60 \mathrm{~dB}$ (Hijau - Kuning)
$: 60 \mathrm{~dB}-65 \mathrm{~dB}$ (Kuning - orange)
$: 65 \mathrm{~dB}-70 \mathrm{~dB}$ (Orange - merah)
$:>70 \mathrm{~dB} \quad($ Merah)




\section{HASIL DAN PEMBAHASAN}

Berdasarkan hasil pengukuran tingkat kebisingan di Kampus A Universitas PGRI Palembang yang telah dilakukan, dapat diketahui dari masingmasing titik yang telah diukur memiliki tingkat kebisingan $\mathrm{L}_{50}, \mathrm{~L}_{1}$ dan $\mathrm{L}_{\mathrm{eq}}$ yang berbeda-beda pada setiap periode waktu pengukuran. Tingkat kebisingan $\mathrm{L}_{50}, \mathrm{~L}_{1}$ dan $\mathrm{L}_{\mathrm{eq}}$ tersebut ditabulasikan kedalam tabel - tabel yang sesuai dengan waktu pengukurannya dan kemudian dibandingkan dengan nilai ambang batas yang diperbolehkan $55 \mathrm{~dB}$ sesuai dengan Keputusan Menteri Lingkungan Hidup No. 48/MENLH/11/1996

Tabel 1. Nilai Tingkat Kebisingan $\mathrm{L}_{50}$, $\mathrm{L}_{1}$, dan $\mathrm{L}_{e q}$ Pengukuran Pagi.

\begin{tabular}{|c|c|c|c|}
\hline \multirow{2}{*}{ Titik } & \multicolumn{3}{|c|}{ Tingkat Kebisingan $(\mathrm{dB})$} \\
\cline { 2 - 4 } & $\mathrm{L}_{50}$ & $\mathrm{~L}_{1}$ & $\mathrm{~L}_{e q}$ \\
\hline 1 & 56,0 & 77,3 & 65,2 \\
2 & 56,1 & 63,9 & 59,5 \\
3 & 54,3 & 61,1 & 57,2 \\
4 & 53,9 & 63,5 & 58,0 \\
5 & 50,0 & 62,5 & 55,4 \\
6 & 49,3 & 55,5 & 51,9 \\
7 & 51,0 & 63,0 & 56,2 \\
8 & 48,4 & 56,2 & 51,7 \\
\hline
\end{tabular}

Tabel 1 dapat dilihat grafik perbadingan nilai kebisingan dengan ambang batas yang telah ditetapkan sebesar $55 \mathrm{~dB}$.

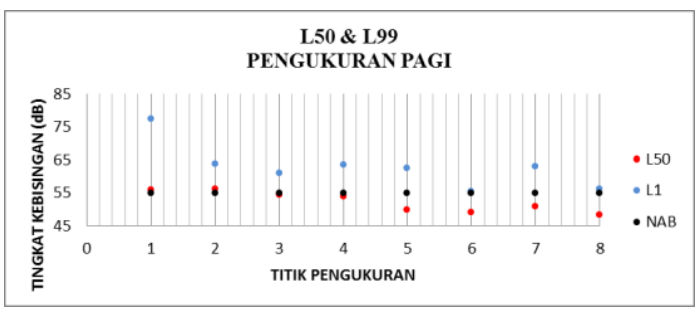

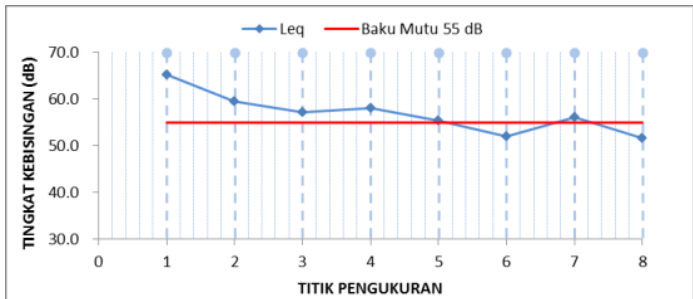

Gambar 3. Fluktuasi $\mathrm{L}_{50}, \mathrm{~L}_{1}$ dan $\mathrm{L}_{\mathrm{eq}}$ Pagi

Tabel 1 dan gambar 3 dapat dijelaskan tingkat kebisingan $\mathrm{L}_{50}, \mathrm{~L}_{1}$ dan $\mathrm{L}_{\mathrm{eq}}$ pengukuran pagi yang dilaksanakan pada saat masuk kerja dan perkuliahan dimulai dari jam 07.00 menunjukkan tingkat kebisingan Leq di titik 1, 2, 3, 4, 5 , dan 7 telah melewati nilai ambang batas, sedangkan untuk titik 5 dan 8 nilai kebisingan Leq masih berada dibawah ambang batas.

Tabel 2.Nilai Tingkat Kebisingan $\mathrm{L}_{50}$, $\mathrm{L}_{1}$, dan $\mathrm{L}_{e q}$ Pengukuran Siang.

\begin{tabular}{|c|c|c|c|}
\hline \multirow{2}{*}{ Titik } & \multicolumn{3}{|c|}{ Tingkat Kebisingan $(\mathrm{dB})$} \\
\cline { 2 - 4 } & $\mathrm{L}_{50}$ & $\mathrm{~L}_{1}$ & $\mathrm{~L}_{e q}$ \\
\hline 1 & 58,2 & 67,4 & 62,2 \\
2 & 58,7 & 71,5 & 64,2 \\
3 & 54,3 & 64,4 & 58,7 \\
4 & 57,5 & 65,1 & 60,7 \\
5 & 53,9 & 57,1 & 55,3 \\
6 & 54,4 & 59,6 & 56,6 \\
7 & 55,1 & 62,3 & 58,2 \\
8 & 49,3 & 64,7 & 55,9 \\
\hline
\end{tabular}

Berdasarkan tabel 2 dapat dilihat grafik perbadingan nilai kebisingan dengan ambang batas yang telah ditetapkan sebesar $55 \mathrm{~dB}$.

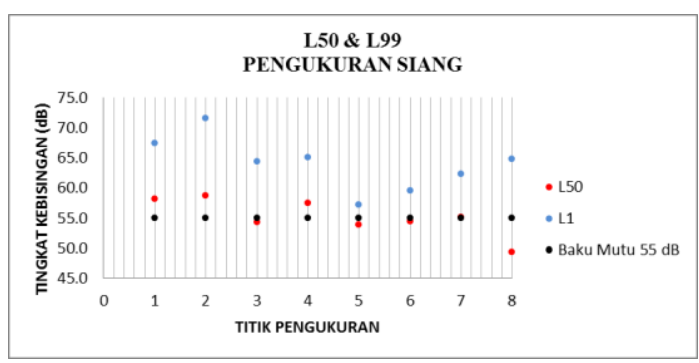




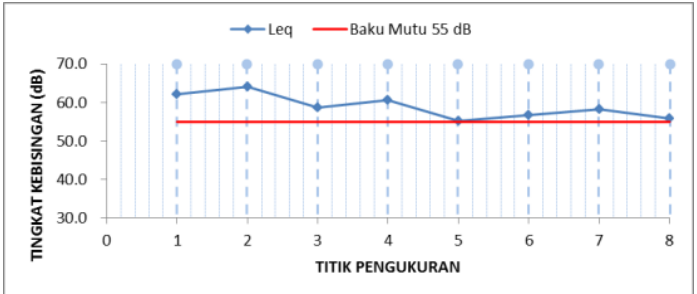

Gambar 4. Fluktuasi $\mathrm{L}_{50}, \mathrm{~L}_{1}$ dan $\mathrm{L}_{\mathrm{eq}}$ Siang

Tabel 2 dan gambar 4 dapat dijelaskan tingkat kebisingan $\mathrm{L}_{50}, \mathrm{~L}_{1}$ dan Leq untuk pengukuran siang dilaksanakan pada saat istirahat siang yang dilmulai dari jam 10.00. Dari semua titik yang berjumlah 8 terdapat peningkatan dibandingkan pada saat pengukuran pagi. Secara keseluruhan 8 titik tersebut mempunyai nilai yang semuanya telah melebihi nilai ambang batas.

Tabel 3. Nilai Tingkat Kebisingan $\mathrm{L}_{50}$,

\begin{tabular}{|c|c|c|c|}
\hline \multicolumn{4}{|c|}{$\mathrm{L}_{1}$, dan $\mathrm{L}_{\text {eq }}$ Pengukuran Sore. } \\
\hline \multirow{2}{*}{ Titik } & \multicolumn{3}{|c|}{ Tingkat Kebisingan $(\mathrm{dB})$} \\
\cline { 2 - 4 } & $\mathrm{L}_{50}$ & $\mathrm{~L}_{1}$ & $\mathrm{~L}_{\text {eq }}$ \\
\hline 1 & 56,2 & 78,2 & 65,7 \\
2 & 55,1 & 80,0 & 65,8 \\
3 & 56,6 & 80,9 & 67,1 \\
4 & 57,5 & 72,4 & 63,9 \\
5 & 57,8 & 63,3 & 60,2 \\
6 & 55,6 & 76,1 & 64,4 \\
7 & 58,2 & 80,1 & 67,6 \\
8 & 53,2 & 66,9 & 59,1 \\
\hline
\end{tabular}

Tabel 3 dapat dilihat grafik perbadingan nilai kebisingan dengan ambang batas yang telah ditetapkan sebesar $55 \mathrm{~dB}$.

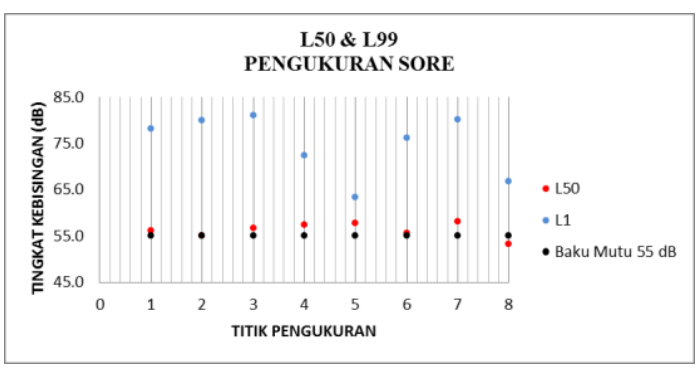

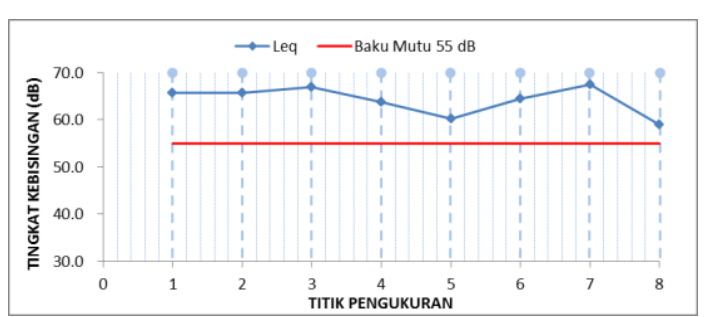

Gambar 5. Fluktuasi $\mathrm{L}_{50}, \mathrm{~L}_{1}$ dan $\mathrm{L}_{\mathrm{eq}}$ Sore

Tabel 3 dan gambar 5 dapat dijelaskan tingkat kebisingan $\mathrm{L}_{50}, \mathrm{~L}_{1}$ dan $\mathrm{L}_{\mathrm{eq}}$ untuk pengukuran sore dilaksanakan pada waktu pulang kerja dan pulang kuliah yang dimulai dari jam 15.00. Secara keseluruhan di semua titik pengukuran nilai kebisingan Leq yang terukur telah melewati ambang batas, sedikit perbedaan dari sebelumnya terdapat peningkatan nilai $\mathrm{L}_{\mathrm{eq}}$ yang signifikan pada titik 7 dibandingkan saat waktu pengukuran sebelumnya.

Pemetaan tingkat kebisingan di Kampus A Universitas PGRI Palembang perlu dilakukan untuk mengetahui pola persebaran kebisingan. Berdasarkan nilai kebisingan $\mathrm{L}_{\text {eq }}$ di setiap titik pengukuran yang telah didapatkan sebelumnya, nilai Leq tersebut di gabungkan sesuai dengan dengan data koordinat $\mathrm{x}$ dan $\mathrm{y}$ di setiap titik yang telah diambil menggunakan GPS sehingga menjadi sebuah peta kontur dengan menggunakan program Surfer 11. Menurut pembagian zona warna peta kontur pada saat pembuatan peta menggunakan program Surfer 11, nilai yang berada pada zona berwarna hijau, kuning, orange dan merah telah melewati nilai ambang batas baku mutu untuk zona sekolah sebesar $55 \mathrm{~dB}$. Hasil pemetaan tingkat kebisingan pada waktu pengukuran pagi, siang, dan sore hari disajikan pada gambar 6 gambar 7, dan gambar 8 . 


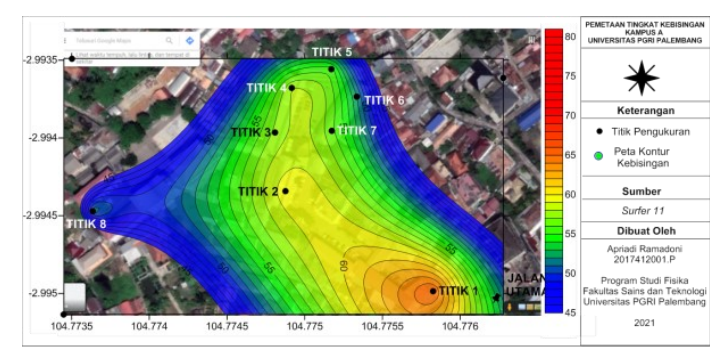

Gambar 6. Peta Kontur Kebisingan $\mathrm{L}_{\mathrm{eq}}$ Kampus A Pada Saat Pengukuran pagi.

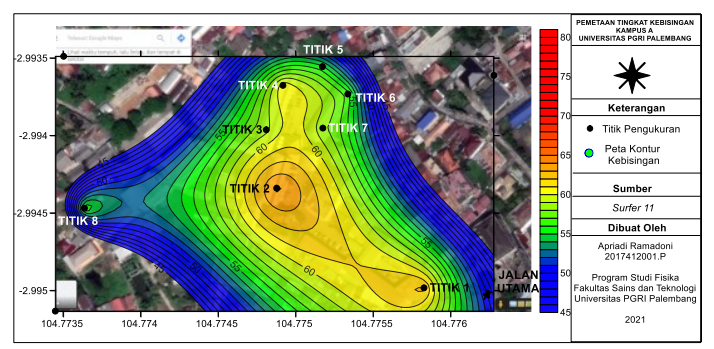

Gambar 7. Peta Kontur Kebisingan $\mathrm{L}_{\mathrm{eq}}$ Kampus A Pada Saat Pengukuran Siang.

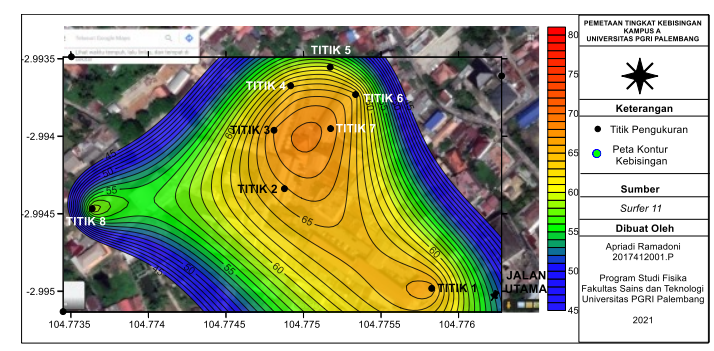

Gambar 8. Peta Kontur Kebisingan $\mathrm{L}_{\mathrm{eq}}$ Kampus A Pada Saat Pengukuran Sore.

Peta kontur kebisingan Leq untuk pengukuran pagi $\left(\mathrm{L}_{1}\right)$ ditunjukkan oleh gambar 6, Berdasarkan gambar, sumber kebisingan yang paling tinggi berada pada titik 1. Dalam peta kontur, titik 1 merupakan Gedung A Rektorat dan Pascasarjana. Gedung tersebut berdekatan dengan jalan masuk kendaraan yang akan menuju lapangan parkir. Sementara di titik lainnya seperti titik 2, titik 3, dan titik 4 nilai kebisingannya berkurang tetapi masih berada di atas ambang batas. Hal ini dikarenakan lokasi titik tersebut masih berada di kawasan lapangan parkir sehingga suara bising kendaraan yang melintas masih bisa terbaca oleh alat pengukur. Sedangkan untuk titik 5 , titik 6 , titik 7 , dan titik 8 pada peta kontur merupakan area gedung perkuliahan yang berdekatan dengan lokasi parkir kendaran. Pada saat pengukuran pagi, lokasi tersebut belum banyak diisi oleh kendaraan sehingga nilainya relatif lebih kecil dibandingkan titik lainnya .

Gambar 7 dapat dilihat gambaran persebaran tingkat kebisingan Leq yang terjadi pada saat pengukuran siang $\left(\mathrm{L}_{2}\right)$ dilakukan. Menurut peta kontur, sumber kebisingan yang paling tinggi berada di titik 2. Titik tersebut di dalam peta menunjukkan lokasi gedung $\mathrm{C}$ Universitas PGRI Palembang. Lokasi gedung tersebut berada disamping jalan koridor masuk kendaraan menuju parkiran yang ada di dalam kampus. Selain itu gedung tersebut merupakan pusat akademik Universitas PGRI Palembang sehingga kegiatan mahasiswa yang berada disana cukup bising pada saat pengukuran siang hari dilakukan selama 6 hari perkuliahan.

Gambar 8 yang merupakan peta kontur kebisingan pada saat pengukuran sore $\left(\mathrm{L}_{3}\right)$ dapat dilihat gambaran sebaran kebisingan yang paling tinggi berada di area titik 2, titik 3 , dan titik 7 . Ketiga titik tersebut merupakan gedung $\mathrm{C}$, gedung $\mathrm{D}$, dan gedung $\mathrm{E}$ kampus yang lokasinya berdekatan dengan tempat parkir kendaraan. Selain itu, titik 1 yang lokasinya berada di jalan masuk kampus menampilkan tingkat kebisingan yang hampir sama dengan ketiga titik tersebut. Hal ini disebabkan oleh aktivitas akademis seperti mahasiswa dan dosen yang bersiap untuk pulang dan kendaraan yang akan meninggalkan area kampus. Berdasarkan hasil penelitian oleh Jumingin dan Ramadhani (2018) yang menyatakan adanya peningkatan volume kendaraan pada daerah traffic light dapat menyebabkan peningkatan kebisingan. Peningkatan tingkat kebisingan pada saat pertandingan sepakbola di Stadion Gelora Jakabaring Palembang dapat diakibatkan oleh peningkatan jumlah penonton dan peningkatan volume bunyi seperti 
dentuman alat musik, terompet, teriakan/sorak sorai penonton, dan suara peluit yang ditiup oleh wasit (Jumingin dkk, 2018).

Penelitian kebisingan Leq di Kampus A Universitas PGRI Palembang selama 6 hari pengukuran yang menghasilkan nilai kebisingan Leq ratarata keseluruhan, peneliti berpendapat sama dengan penelitian terdahulu yang dilakukan oleh Atina dkk (2020) yang menyatakan bahwa tingkat kebisingan yang terukur di lingkungan kampus A Universitas PGRI Palembang belum memenuhi standar baku mutu pemerintah untuk lembaga pendidikan yaitu $55 \mathrm{~dB}$. Pendapat ini didukung oleh hasil tabel, grafik, dan peta kontur tingkat kebisingan Leq yang telah dibuat sebelumnya, bahwa tingkat kebisingan yang terukur di setiap titik hampir semuanya telah melewati ambang batas $55 \mathrm{~dB}$ kecuali di titik 6 dan titik 8 pada saat pengukuran pagi.

\section{KESIMPULAN}

1. Tingkat kebisingan suara yang ada di Kampus A Universitas PGRI Palembang telah melewati ambang batas baku mutu sebesar $55 \mathrm{~dB}$.

2. Pemetaan kebisingan suara yang terjadi di Universitas PGRI Palembang menunjukkan sebaran kebisingan yang tinggi dan melebihi ambang batas baku mutu sebesar $55 \mathrm{~dB}$ khususnya di area parkir kendaraan dan pintu masuk utama kampus yang diwakili oleh titik 1 dan titik 2 pada peta kontur.

\section{DAFTAR PUSTAKA}

Ahmad, F., Handayani, I. D., \& Margiantono, A. (2018). Analisis Tingkat Kebisingan di Universitas Semarang dengan Peta Kontur Menggunakan Software Golden 1. Elektrika, 10(2), 22-27.
Atina, A., Jumingin, J., Rahmadani, W., \& Sukria, I. (2020). Analisis Tingkat Kebisingan di Lingkungan Universitas PGRI Palembang. Sainmatika: Jurnal Ilmiah Matematika dan Ilmu Pengetahuan Alam, 17(2), 126-132.

Aulia, A. F. (2018). Analisis dan Pemetaan Tingkat Kebisingan pada Kawasan Pendidikan/Sekolah (Studi kasus: SMA Kartika I-1 Medan dan SMP Kartika I-1 Medan). Skripsi. Program Studi Teknik Lingkungan, Fakultas Teknik, Universitas Sumatera Utara, Medan.

Jumingin, J., \& Ramadhani, M. (2018). Analisis Faktor Lokasi Pengukuran Terhadap Tingkat Kebisingan (Studi Kasus: Jalan Demang Lebar Daun Kota Palembang). Sainmatika: Jurnal Ilmiah Matematika dan Ilmu Pengetahuan Alam, 15(1), 62-68.

Jumingin, J., \& Atina, A. (2019). Reduksi Tingkat Kebisingan Kendaraan Bermotor Dengan Penghalang Alami Berupa Panjang Klaster Tanaman. Sainmatika: Jurnal Ilmiah Matematika dan Ilmu Pengetahuan Alam, 16(2), 137-143.

Jumingin, J., Setiawan, A. A., \& Hartono, H. (2018). Pengaruh Menit Pertandingan Sepakbola dengan Tingkat Kebisingan di Stadion Gelora Sriwijaya Jakabaring Palembang (Studi Kasus: Pertandingan SFC Vs PS Tira). Sainmatika: Jurnal Ilmiah Matematika dan Ilmu Pengetahuan Alam, 15(2), 118-122.

Keputusan Menteri Lingkungan Hidup No. 48, (1996). Baku Tingkat Kebisingan.

Saputra, E. K., A. Sasmita, \& Andrio, D. (2016). Analisis Tingkat Kebisingan di Kawasan Kampus Fakultas Kedokteran Univeritas Riau. Jom FTEKNIK, 3(2): 1 - 4 .

SNI 7231. (2009). Metode Pengukuran Intensitas Kebisingan di Tempat Kerja. Badan Standarisasi Nasional. Jakarta.

Sumiyati, S., \& Huboyo, H. S. (2008). Buku Ajar Pengendalian Bising dan Bau. Program Studi Teknik Lingkungan. Universitas Diponegoro. Semarang. 